\title{
Marked variations in gut microbiota and some innate immune responses of fresh water crayfish, marron (Cherax cainii, Austin 2002) fed dietary supplementation of Clostridium butyricum
}

Md Javed Foysal ${ }^{\text {Corresp., } 1,2}$, Thi Thu Thuy Nguyen ${ }^{1}$, Md Reaz Chaklader $^{1}$, Muhammad A.B. Siddik $^{1}$, Chin-Yen Tay ${ }^{3}$, Ravi Fotedar ${ }^{1}$, Sanjay Kumar Gupta ${ }^{4}$

${ }^{1}$ School of Molecular and Life Sciences, Curtin University, Bentley, Western Australia, Australia

Department of Genetic Engineering and Biotechnology, Shahjalal University of Science \& Technology, Sylhet, Bangladesh

3 Helicobacter Research Laboratory, Marshall Centre for Infectious Disease Research and Training, School of Biomedical Sciences, University of Western Australia, Perth, Western Australia, Australia

4 ICAR-Indian Institute of Agricultural Biotechnology, Ranchi, Jharkhand, India

Corresponding Author: Md Javed Foysal

Email address: mdjaved.foysal@postgrad.curtin.edu.au

This study aimed to investigate the effects of Clostridium butyricum as a dietary probiotic supplement in fishmeal based diet on growth, gut microbiota and immune performance of marron (Cherax cainii). Marron were randomly distributed into two different treatment groups, control and probiotic fed group. After 42 days of feeding trial, the results revealed a significant $(P<0.05)$ increase in growth due to increase in number of moults in marron fed probiotics. The probiotic diet also significantly enhanced the total haemocyte counts (THC), lysozyme activity in the haemolymph and protein content of the tail muscle in marron. Compared to control, the 16S rRNA sequences data demonstrated an enrichment of bacterial diversity in the probiotic fed marron where significant increase of Clostridium abundance was observed. The abundance for crayfish pathogen Vibrio and Aeromonas were found to be significantly reduced post feeding with probiotic diet. Predicted metabolic pathway revealed an increased activity for the metabolism and absorption of carbohydrate, degradation of amino acid, fatty acid and toxic compounds, and biosynthesis of secondary metabolites. $C$. butyricum supplementation also significantly modulated the expression level of immune-responsive genes of marron post challenged with Vibrio mimicus. The overall results suggest that $C$. butyricum could be used as dietary probiotic supplement in marron aquaculture. 
1 Marked variations in gut microbiota and some innate immune responses of fresh water

2 9 Technology, Sylhet, Bangladesh

Md Javed Foysal
Running title: Effects of C. butyricum on marron health

Md Javed Foysal 1,2*, Thi Thu Thuy Nguyen ${ }^{1}$, Md Reaz Chaklader ${ }^{1}$, Mohammad A.B. Siddik ${ }^{1}$, Alfred Chin Yen Tay ${ }^{3}$, Ravi Fotedar ${ }^{1}$, Sanjay Kumar Gupta ${ }^{4}$

${ }^{1}$ School of Molecular and Life Sciences, Curtin University, Bentley, WA, Australia

${ }^{2}$ Department of Genetic Engineering and Biotechnology, Shahjalal University of Science and

${ }^{3}$ Helicobacter Research Laboratory, Marshall Centre for Infectious Disease Research and Training, School of Biomedical Sciences, University of Western Australia, Perth, WA, Australia ${ }^{4}$ ICAR-Indian Institute of Agricultural Biotechnology, Ranchi, Jharkhand, India

${ }^{*}$ Corresponding author:

School of Molecular and Life Science, Curtin University, Bentley, WA, Australia

Email address: mjfoysal-geb@sust.edu or mdjaved.foysal@postgrad.curtin.edu.au

Telephone: +6189266 4508: mobile +61451404337

ORCID: https://orcid.org/0000-0002-2064-8897 


\section{Marked variations in gut microbiota and some innate immune responses of fresh water crayfish, marron (Cherax cainii, Austin 2002) fed dietary supplementation of Clostridium butyricum}

\section{ABSTRACT}

This study aimed to investigate the effects of Clostridium butyricum as a dietary probiotic supplement in fishmeal based diet on growth, gut microbiota and immune performance of marron (Cherax cainii). Marron were randomly distributed into two different treatment groups, control and probiotic fed group. After 42 days of feeding trial, the results revealed a significant $(\mathrm{P}<0.05)$ increase in growth due to increase in number of moults in marron fed probiotics. The probiotic diet also significantly enhanced the total haemocyte counts (THC), lysozyme activity in the haemolymph and protein content of the tail muscle in marron. Compared to control, the 16S rRNA sequences data demonstrated an enrichment of bacterial diversity in the probiotic fed marron where significant increase of Clostridium abundance was observed. The abundance for crayfish pathogen Vibrio and Aeromonas were found to be significantly reduced post feeding with probiotic diet. Predicted metabolic pathway revealed an increased activity for the metabolism and absorption of carbohydrate, degradation of amino acid, fatty acid and toxic compounds, and biosynthesis of secondary metabolites. C. butyricum supplementation also significantly modulated the expression level of immune-responsive genes of marron post challenged with Vibrio mimicus. The overall results suggest that $C$. butyricum could be used as dietary probiotic supplement in marron aquaculture. 


\section{INTRODUCTION}

48 Crayfish harbour complex bacterial communities in the intestine that stimulates various host

49

50

51

52

53

54 functions like digestion, absorption, immunity and disease resistance (Skelton et al., 2017). Augmentation in the growth and immunity of fish and crayfish with dietary probiotic supplements has long been studied (Ambas, Fotedar, \& Buller, 2017; Ambas, Suriawan, \& Fotedar, 2013; Didinen et al., 2016; Panigrahi et al., 2007). Probiotics are live microorganisms that can improve the digestive function by influencing the growth of beneficial microorganisms in the gut when administered in adequate amounts (Irianto \& Austin, 2002; Dawood et al., 2016). Probiotic bacteria can improve the growth, immune response, feed utilization and stress response of fish (Kesarcodi-Watson et al., 2008; Iwashita et al., 2015; Dawood et al., 2016) in the host species. Among the bacterial supplements, majority of the studies focussed on the beneficial effects of Lactic acid bacteria (LAB), especially Lactobacillus species on growth, immunity and disease resistance of fish and crayfish (Pirarat et al., 2006; Didinen et al., 2016; Zheng et al., 2017). Clostridium butyricum, a short-chain butyric acid producing bacteria that resides in healthy intestinal flora, has been used as diet supplements to enhance the growth and immune response of fish and broiler chicken (Song et al., 2006; Gao et al., 2013; Zhang et al., 2014; Ramírez et al., 2017). In addition, C. butyricum as probiotic supplement demonstrated to have inhibitory effects against the colonization of pathogenic bacteria including species from Vibrio and Aeromonas in the fish gut (Pan et al., 2008; Gao et al., 2013). However, the impacts of C. butyricum on crayfish, especially on marron (Cherax cainii) growth performance, gut microbiota and immune gene expression has yet to be explored.

Peer) reviewing PDF | (2019:01:34753:1:1:NEW 18 Jul 2019) 
68 Marron is the third largest freshwater crayfish and iconic to Western Australia (WA). The global

69 demands of marron is very high due to its large harvest size (up to $2 \mathrm{~kg}$ ), distinctive flavour,

70 disease-free status, high consumer preference, and ability of live transport (Ambas, Suriawan, \&

71 Fotedar, 2013). Slow growth of marron has long been a bottleneck in the expansion of marron

72 aquaculture in WA (Lawrence, 2007; Alonso, 2010; Department of Fisheries, 2017). Although

73 there has not been any current report of infection in marron, future expansion of marron industry

74 could bring this threat especially infections by Vibrio species (Eaves \& Ketterer, 1994; Bean et al.,

75 1998; Sherry et al., 2016). Therefore, enhancing growth parameters and minimizing the possible

76 incidences of Vibrio infections are the two utmost challenges in the expansion of marron

77 aquaculture.

78 Integration of traditional growth performance analysis methods with recently developed modern

79 technologies like 16S rRNA based high throughput sequencing and bioinformatics pipelines have

80 enabled more comprehensive analysis of feeding effects at a cellular and molecular level of fish

81 (Allali et al., 2017; Miao et al., 2018). In addition, quantitative real-time polymerase chain reaction

82 (PCR) has been widely used to measure the relative expression level of immune responsive genes

83 for fish (Mahanty et al., 2017). The present investigation was designed to evaluate the effects of

84 dietary supplementation of $C$. butyricum on health, gut microbial community and immune related 85 gene expression of marron.

86 MATERIALS AND METHODS

\section{Experiment set-up}

88 A total of 24 marron with a mean weight of $69.65 \pm 1.04 \mathrm{~g}$ were transported alive from Blue Ridge

89 Marron, Manjimup, $\left(34.2019^{\circ} \mathrm{S}, 116.0170^{\circ} \mathrm{E}\right)$ to Curtin Aquatic Research Laboratory (CARL), 
90 Bentley campus, Curtin University, Western Australia. Marron were then randomly distributed

91 into six different tanks (150 L capacity) and acclimatized for two weeks before starting the feeding

92 trial. During acclimatization, marron were fed with commercial basal diet named marron pellet

93 (Glenn Forest, Perth, Australia), composed of 28\% crude protein, 9\% crude fat, 8.5\% moisture,

94 and 5\% crude ash. After acclimatization, marron were disseminated into two distinct treatment

95 groups' viz. control and probiotic fed group with a stocking density of four marron per tank.

96 Constant aeration to each tank was distributed by air stones (Aqua One, Perth, Australia) and fixed

97 temperature of $22 \pm 0.5^{\circ} \mathrm{C}$ was maintained using submersible thermostat set (Aqua One, Perth,

98 Australia). Each marron were individually nurtured in a special cage prepared of plastic mesh (0.8-

$998.0 \mathrm{~mm}$ thickness) to avoid cannibalism as described previously (Ambas, Suriawan, \& Fotedar,

100 2013). Approximately 30\% of water was exchanged every day from each tank to remove uneaten

101 feed and faecal debris by siphoning.

\section{Probiotic feed formulation}

103 The probiotic feed was formulated at CARL according to the procedure used by Ambas, Suriawan, $104 \&$ Fotedar, (2013). The fishmeal based basal diet was used for probiotic feed formulation (Table 1). The ingredients of the commercial basal feed were gently passed through $100 \mu \mathrm{m}$ mesh sieve

106 and homogenized to get uniform particle size. C. butyricum purchased from Advanced 107 Orthomolecular Research (AOR, Calgary, Canada) was cultured on Clostridial Agar (Sigma108 Aldrich, MO, USA) followed by sub-culture on Clostridial agar. Then a serial dilution and 109 subsequent plate counts were performed to obtain the desire bacterial concentration. The bacteria 110 (C. butyricum) were then added at $10^{7} \mathrm{CFU} / \mathrm{mL}$ per $\mathrm{kg}$ of feed as described in previous studies 111 (Ramírez et al., 2017) and mixed uniformly. Pellet were prepared with mince mixture followed by 112 vacuum drying oven at $37{ }^{\circ} \mathrm{C}$ for overnight and storage at $4{ }^{\circ} \mathrm{C}$ until used. Final proximate 
113 compositions and bacterial concentration of diets were determined as per the method of

114 Association of Official Analytical Chemists, AOAC (AOAC, 2006) and plate counts on Clostridial

115 agar (Table 1). During experimental trial, each marron were fed once every day at 5 PM for 42

116 days at a rate of $1.5 \%$ of total marron biomass per tank (Ambas, Fotedar, \& Buller, 2017). Control

117 group fed basal diet and probiotic group served C. butyricum supplemented diet.

118 Monitoring of water quality parameters

119 The temperature and $\mathrm{pH}$ of experimental tank water was measured using portable waterproof $120{ }^{\circ} \mathrm{C} / \mathrm{mV} / \mathrm{pH}$ meter (CyberScan pH 300, Eutech Instruments, Singapore). The levels of dissolved 121 oxygen (DO) in water was monitored by digital DO meter (YSI55, Perth Scientific, Australia). 122 The concentrations of nitrate $\left(\mathrm{NO}_{3}^{-}\right)$and nitrite $\left(\mathrm{NO}_{2}^{-}\right)$were checked using Hach $\mathrm{DR} / 890$ 123 Colorimeter (Hach, Loveland, CO, USA) following the method of cadmium reduction and 124 diazotization (Hoang et al., 2016). Phosphate $\left(\mathrm{PO}_{4}^{-}\right)$level in water was examined by ascorbic acid 125 standard 4500-PE method, as described by Huong Mai, Fotedar, \& Fewtrell, 2010. The 126 concentrations of ammonia $\left(\mathrm{NH}_{3}\right)$ in water was monitored using ammonia test kit (Hach, Loveland, 127 CO, USA).

\section{Marron sampling}

129 For analysis of haemolymph parameters (lysozyme, haemolymph osmolality and total haemocyte 130 count) health indices (protein and energy in tail muscle), one randomly selected marron from each 131 tank $(\mathrm{N}=6)$ was selected. However, for DNA extraction and microbiome analysis, two randomly 132 selected marron from each tank $(\mathrm{N}=12)$ were scarified followed by careful separation of hindgut. 133 The hindgut contents of two samples from each tank were homogenized and pooled together $(\mathrm{N}=$ 134 6), and then transferred into $1.5 \mathrm{~mL}$ Eppendorf. Finally, for immune gene expression, the whole 
135 intestine tissue sample from one randomly selected marron from each tank $(\mathrm{N}=6)$ was used after

136 challenge test. Sample from each marron was used for the haemolymph parameters (before

137 sacrifice), biochemical assay (after sacrifice), and molecular analysis (microbiome and gene

138 expression).

\section{Analysis of growth and immune parameters}

140 Before starting the experiment and at the end of the trial, the weight of each marron was recorded.

141 The weight gain (WG), specific growth rate (SGR) and feed conversion ratio (FCR) were measured

142 at the end of the experiment according to Ambas, Fotedar, \& Buller, 2017. The number of moults

143 in each tank was monitored carefully. For analysis of immune parameters like haemolymph

144 osmolality (HO), lysozyme and total haemocyte counts (THC), the haemolymph was extracted

145 carefully from the pericardial cavity of marron with a $0.5 \mathrm{~mL}$ syringe containing $0.1 \mathrm{~mL}$ pre-cooled

146 anticoagulant $(0.1 \%)$ glutaraldehyde in $0.2 \mathrm{M}$ sodium cacodylate, $(\mathrm{pH} 7.0 \pm 0.2)$. The $\mathrm{HO}$ of marron

147 was measured using Cryoscopic Osmometer-Osmomet 030 (Gonotec, Berlin, Germany) as

148 described by Sang \& Fotedar, 2004. THC of the extracted haemolymph from each replicate of

149 two treatment group was calculated under a hemocytometer (Nauabuer, Germany) with 100X

150 magnification according to method described by Ambas, Fotedar, \& Buller, 2017. The lysozyme

151 activity of marron haemolymph in control and probiotic fed groups was measured using

152 turbidimetric assay (Mai \& Fotedar, 2018; Foysal et al., 2019). Briefly, $50 \mu \mathrm{L}$ of hemolymph

153 samples (anticoagulant added) were disseminated into 96-well microtiter-plate (Iwaki, Tokyo,

154 Japan). After incubation for $15 \mathrm{~min}$ at room temperature, $50 \mu \mathrm{L}$ of PBS $(0.25 \mathrm{mg} / \mathrm{mL})$ suspended

155 Micrococcus lysodeiktikus (Sigma-Aldrich, St. Louis, MO, USA) solution was added into separate

156 wells of the same plate. The absorbance of each well in the microtiter-plate was then monitored in

157 a MS212 reader (Titertek Plus, Tecan, Grodig, Austria) at $450 \mathrm{~nm}$ wavelength according to 
158 manufacturer's instructions. The assay was based on the rate of Micrococcus lysodeiktikus cell

159 lysis in terms of absorbance change caused by lysozyme in the hemolymph. The measurements

160 were taken at every 2 minute intervals for $20 \mathrm{~min}(\mathrm{U} / \mathrm{mL})$.

\section{Analysis of biochemical composition}

162 The protein and energy content in the tail muscle and fat content in the hepatopancreas were 163 measured according to methods described by the Association of Official Analytical Chemists, 164 AOAC international (AOAC, 2006). The percentage of crude protein in oven dried tail muscle was 165 measured following Kjeldahl method $(\mathrm{N} \times 6.25)$ in Kjeltec Auto 1030 analyser (Foss Tecator, 166 Höganäs, Sweden) (Jim, Garamumhango \& Musara, 2017). Fat content in hepatopancreas was 167 analysed following Soxhlet ether extraction method using Soxtec System HT6 (Tecator, Höganäs, Sweden) (Jim, Garamumhango \& Musara, 2017). The amount of total gross energy in the tail muscle was calculated using bomb calorimeter (Heitersheim, Germany).

\section{High throughput sequencing}

171 At the end of the experiment, gut samples prepared as described in marron sampling were used for

172 DNA extraction. Due to special role in digestion, absorption and immunity, hindgut was selected 173 for 16S rRNA sequencing (Wang et al., 2018). The bacterial DNA was extracted using DNeasy 174 Blood and Tissue Kit (Qiagen, Crawley, UK) following manufacturer's instructions. Extracted 175 DNA was checked for quantity in a NanoDrop Spectrophotometer (Thermo Fisher Scientific, 176 Waltham, MA, USA) and diluted to $30 \mathrm{ng} / \mu \mathrm{L}$ as final concentration. Thirty cycles of PCR 177 amplification were performed in a BioRad S100 Gradient Thermal Cycler (Bio-Rad Laboratories, 178 Inc., Foster City, California, USA) with V3-V4 sequencing primers (Part \# 15044223 Rev. B) and 179 Hot Start Taq 2X Master Mix (BioLab Inc., Australia). Amplified PCR products were separated 
180 by $1 \%$ agarose gel and visualized under a gel documentation system (FujiFilm LAS-4000 Image

181 Analyzer, Boston Inc., Foster City, California, USA). Secondary PCR was applied for the

182 barcoding of 16S rRNA PCR amplicon of each sample according to the Illumina standard protocol

183 (Part \# 15044223 Rev. B). The samples were then sequenced up to 20,000 reads on an Illumina

184 MiSeq platforms (Illumina Inc., San Diego, California, USA) at Harry Perkins Institute of Medical

185 Research, Western Australia, using a v3 kit (600 cycles, Part \# MS-102-3003).

186 Gene expression analysis in challenged marron

187 Six genes, namely, interleukin 8 , interleukin 10, interleukin $17 \mathrm{~F}$, cathepsin L, prophenoloxidase 188 and cytosolic manganese superoxide dismutase (IL-8, IL-10, IL-17F, PcCTSL, proPO and 189 cytMnSOD) that have been reported to be associated with innate immunity of fish and crayfish 190 (Liu et al., 2013; Jiang et al., 2015; Dai et al., 2017; Miao et al., 2018) were selected. The primers used for the selected genes are listed in Table 2. Crayfish pathogen Vibrio mimicus was collected 192 from the Department of Food and Agriculture, Western Australia. At the end of the feeding trial, each selected marron was injected with previously prepared $2 \times 10^{8} \mathrm{CFU} / \mathrm{mL}$ stock solution of $V$. mimicus (Ambas, Suriawan, \& Fotedar, 2013). Fifty microliters of bacterial solution were injected through the base of the fifth thoracic leg of marron (Ambas, Suriawan, \& Fotedar, 2013). Control marron were injected with $50 \mu \mathrm{L}$ of phosphate buffer saline (PBS). Injected marron were subjected to RNA extraction from intestine tissue after $24 \mathrm{~h}$ of bacterial challenge. For RNA extraction, intestine tissue samples from challenged marron were initially stored at $-80{ }^{\circ} \mathrm{C}$ with $R N A$ Later solution (Sigma-Aldrich, Germany). The samples were thawed, dried, homogenized, ground into fine powder, and finally pooled together according to groups prior to use for RNA extraction. 
204 DNA related impurities. The quality and quantity of the extracted RNA was checked in $1 \%$ gel 205 electrophoresis and NanoDrop spectrophotometer 2000c (Thermo Fisher Scientific, USA). The

206

207

208

209

210

211

212

213

214

215

216

217

218

219

220

221

222

223

224

225

226

cDNA library was prepared using Omnicript RT kit (Qiagen, Hilden, Germany) from $1 \mu \mathrm{g}$ of RNA. Real-time PCR amplification was performed using PowerUp ${ }^{\mathrm{TM}}$ Cyber Green Master Mix (Thermo Scientific, USA) with 7500 Real-Time PCR System (Applied Biosystems, USA) to measure the relative expression level of six selected genes. The relative expression pattern of each target gene in two different groups was calculated using the $2^{-\Delta \Delta \mathrm{CT}}$ method, after normalisation against $\beta$-actin reference gene.

\section{Bioinformatics}

Unless any modifications mentioned, the "pipelines" for downstream sequence analysis and bioinformatics were used with default parameters. After extraction, the initial quality of 16S rRNA sequences were checked in fastQC pipelines (Andrews, 2010). Sickle program was used for the trimming of quality reads (Joshi \& Fass, 2011). Following trimming, reads having a length of less than $200 \mathrm{bp}$ were discarded. MeFiT pipeline was used for the joining of overlapping pair-ends reads (Parikh et al., 2016). Filtering of chimeric sequences, de novo greedy clustering of 16S rRNA sequences into Operational Taxonomic Units (OTUs) at 97\% similarity threshold and removal of singleton OTUs were conducted using micca otu (version 1.7.0) (Albanese et al., 2015). Taxonomic assignment of the representative OTUs was performed using mica classify against SILVA 132 database clustered at 97\% identity (Quast et al., 2013). Multiple sequence alignment of the obtained OTUs was performed using PASTA algorithm (Mirarab et al., 2015). The rarefaction depth value was set at 4672 and subsequent calculation of alpha and beta diversities was performed using QIIME pipeline (version 1.9.1) (Kuczynski et al., 2012). Briefly, the alpha diversity was calculated based on observed species and diversity indices (Shannon, Simpson, 
227 Alpha Fisher and Chao1) using vegan package in Rstudio (Oksanen et al., 2018). Non-parametric $228 t$-test for two samples was performed to compare the alpha diversity metrics between the control 229 and probiotic-fed samples. Principle coordinates analysis (PCoA) was performed to visualize 230 separation of samples using Bray-Curtis and jaccard abundance metrics. Non-parametric statistical 231 test of the distance metric was done using ANOSIM (1000 permutations). PCoA plots were 232 generated using PhyloToAST software (Dabdoub et al., 2016). The assigned bacterial genus from 233 two different feeding groups were plotted in Venn diagram, generated using FunRich tool (Benito234 Martin \& Peinado, 2015). Indicator bacterial genus in two different conditions was differentiated 235 from rarefy 16S rRNA sequence data using Linear Discriminant Analysis Effect Size, LEfSe 236 (University of Auckland, New Zealand) (Segata et al., 2011). For predicting the metabolic 237 pathways through 16S rRNA sequences of two different fed groups, Piphillin pipeline 238 (http://secondgenome.com/Piphillin) was applied with supports of KEGG (May, 2017 release), 239 BioCyc 21.0 databases and LEfSe algorithm (Segata et al., 2011; Iwai et al., 2016). One way 240 analysis of variance (ANOVA) was used to calculate any significant differences $(\mathrm{P}<0.05)$ among 241 the numerical data including growth (WG, SGR, FCR), biochemical compositions (protein, fat, 242 energy), lysozyme, haemolymph osmolality and THC obtained from two different feeding 243 conditions.

\section{Calculations}

245 Following calculations were used:

246 Weight gain, $\mathrm{WG}=[($ mean final body weight - mean initial body weight $)] /[$ mean initial body 247 weight] (Ramirez et al., 2017) 
248 Specific growth rate, SGR $(\%$ day $)=[(\ln$ mean final body weight $-\ln$ mean

249 initial body weight)/number of days $] \times 100$ (Ambas et al., 2017)

250 Feed conversion ratio, FCR = feed intake (dry weight)/weight gain (wet g) (Ramirez et al., 2017)

251 Haemolymph osmolality, $\mathrm{HO}=3 \times$ osmolality of the mix $-2 \times$ osmolality of anticoagulant (Sang

252 \& Fotedar, 2004)

253 Total haemocyte counts, THC $=($ cells counted $\mathrm{x}$ dilution factor $\mathrm{x} 1000) /$ volume of grid $\left(0.1 \mathrm{~mm}^{3}\right)$

254 (Ambas et al., 2017)

255 RESULTS

\section{Water quality parameters}

257 The water quality parameters were recorded within the normal range for optimum growth of marron according to Nugroho \& Fotedar, (2013). Temperature was maintained at $22.3 \pm 0.014-$

$25922.4 \pm 0.01^{\circ} \mathrm{C}, \mathrm{pH}$ was recorded within the range of $7.5 \pm 0.01-7.6 \pm 0.01$, dissolved oxygen

260 levels between $6.51 \pm 0.01$ and $6.65 \pm 0.01$, nitrate and nitrite concentration of $0.046 \pm 0.01-$

$2610.049 \pm 0.01$ and $0.015 \pm 0.01-0.018 \pm 0.01$ were recorded, phosphate concentration was found

262 to be varied within the range of $0.36 \pm 0.01-0.52 \pm 0.02$, and ammonia concentration of $0.20 \pm$ $2630.01-0.22 \pm 0.01$ was observed in water during the experiment.

\section{Probiotic supplement enhanced the growth and haemolymph parameters}

265 After 42 days, the marron in the probiotic fed tanks gained significant $(\mathrm{P}<0.05)$ weight gain $(\mathrm{WG})$ and specific growth rate (SGR) than the control (Table 3). A total of 11 marron were moulted in the probiotic fed tanks compared to three in the control tanks, shown significant $(\mathrm{P}<0.05)$ increase of moult number in probiotic fed marron. Multiple regression analysis revealed a strong "Pearson" 
269 correlation (0.99) between the number of moults and weight gain (Figure 1A). PCoA plot also

270 revealed a complete separation of probiotic fed group based on moulting numbers and weight gain

271 (Figure 1B). Probiotic diet also exhibited significant $(\mathrm{P}<0.05)$ impacts on two out of three

272 haemolymph parameters, total haemocyte counts (THC) and lysozyme. Among two tail muscle

273 parameters, significant $(\mathrm{P}<0.05)$ increase in protein content was observed in probiotic fed marron

274 while the variations were insignificant $(\mathrm{P}>0.05)$ for total gross energy, and fat in the

275 hepatopancreas in the marron fed probiotic feed (Table 2).

276 Probiotic diet modulated the microbial communities in the distal gut

277 The probiotic supplemented diet exhibited a distinct effect on gut microbial community of marron

278 after feeding trial (Figure 2). The 16S rRNA sequence from eight pooled hindgut samples

279 generated 128,567 high quality reads after quality trimming and removing singletons, that were

280 classified into 83 OTUs and 49 genus. Besides 18 shared genus in both groups (control and

281 probiotic), the probiotic feed group had an additional 31 unique genus compared to four in control

282 diet group, indicating higher species diversity (Figure 3). At phylum level, control diet group

283 dominated by the Proteobacteria (96.5\%) while Fusobacteria (53.4\%) and Proteobacteria

$284(44.1 \%)$ shared $97.5 \%$ of OTUs in the probiotic fed group (Figure 4A). At genus level, control

285 group demonstrated more abundance for Aeromonas (47.1\%) and Vibrio (31.8\%) whereas in

286 probiotic fed group, Hypnocyclicus (57.7\%) was the most dominant bacteria, followed by Vibrio

287 (13.1\%) and Aeromonas (9.7\%). A significant reduction of Vibrio (13.1\%) and Aeromonas (9.7\%)

288 counts was noticed in the probiotic fed group at the end of the trial (Figure 4B). Although the

289 values for major diversity indices such as Shannon, Simpson, Fisher Alpha and Chaol were

290 significantly $(\mathrm{P}<0.05)$ higher but more pronounced effects was observed only for Shannon

$291(\mathrm{P}<0.001)$ and Simpson $(\mathrm{P}<0.005)$ indices in the probiotic fed group (Table 4).

Peer] reviewing PDF | (2019:01:34753:1:1:NEW 18 Jul 2019) 
292 Probiotic diet modified the microbial lineages and metabolic pathways in the hindgut

293 Linear discriminant analysis effect size (LEfSe) based on Wisconsin non-parametric t-test at 0.05

294 level of significance revealed three bacterial genus namely, Illumatobacter, Clostridium and

295 Cyanobium to be enriched with C. butyricum supplementation in the marron (Figure 5A). No

296 significant $(\mathrm{P}>0.05)$ enrichment of bacteria was observed in the control group. Piphillin and LEfSe

297 based metabolic pathways extracted from KEGG database predicted an increased pathway

298 activities for carbohydrate metabolism and absorption, amino acid metabolism, catabolism of fatty

299 acid, degradation of toxic and synthetic compounds and biosynthesis of secondary metabolites in

300 the probiotic fed group. In contrast, the analysis predicted significantly higher galactose, hormone

301 and vitamin metabolism activities in the control group (Figure 5B).

Probiotic feed up-regulate the expression profile of immune responsive genes

303

304

305

306

307

308

309

310

311

312

The results of qRT-PCR for the selective genes associated with crayfish immune response post invivo challenge demonstrated significant $(\mathrm{P}<0.05)$ up-regulation of pro-inflammatory cytokine (interleukin 17, IL17), anti-inflammatory cytokine (interleukin 10, IL10), cytosolic manganese superoxide dismutase (cytMnSOD) and prophenoloxidase (proPO). After $24 \mathrm{~h}$ of challenge, results revealed that the relative expression level of IL-17, IL-10, cytMnSOD and proPO were increased by $2.8,2.5,2.2$ and 1.9 folds, respectively (Figure 6). The expression level of cathepsin L (PcCTSL) and interleukin 8 (IL-8) genes were relatively static during post challenge test.

\section{Survival rate}

At 24 and 96 h post-challenge, all marron injected with $V$. mimicus and PBS remained alive and started to respond to the feed given on day 5. The PBS injected marron, however, remained actively 
313 responsive to the feed given earlier (day 3) than bacteria injected marron. No signs of diseases

314 were observed in any of the injected marron.

315 Data availability

316 The raw FASTQ files are currently available in National Centre for Biotechnology Information

317 (NCBI) BioProject under the accession number PRJNA515886.

318 DISCUSSION

319 Probiotics as a dietary supplement have been in vogue for past 10 years for crayfish aquaculture

320 to promote growth, disease resistance and stress tolerance (Ambas, Fotedar, \& Buller, 2017;

321 Ambas, Suriawan, \& Fotedar, 2013; Li, Tan, \& Mai, 2009; Zheng, Duan, Dong, \& Zhang, 2017).

322 Most of the earlier researches on probiotics studies in aquatic animals were performed with the 323 dietary inclusion of Bacillus and Lactobacillus species (Ambas, Fotedar, \& Buller, 2017; Ambas, 324 Suriawan, \& Fotedar, 2013; Kongnum \& Hongpattarakere, 2012; Zheng, Duan, Dong, \& Zhang, 325 2017). However, a very few studies highlighted the importance of using C. butyricum as possible 326 dietary probiotic candidate for crayfish (Ramírez et al., 2017). Results conducted with $C$. 327 butyricum as dietary probiotic supplements demonstrated positive influence on growth and 328 immune parameters of fish, chicken, piglet etc. (Song et al., 2006; Pan et al., 2008; Gao et al., 329 2013; Abdel-Latif et al., 2018; Chen et al., 2018). Reports also have shown that C. butyricum 330 supplementation promote growth performance, body protein content of Pacific white leg shrimp, 331 Lotopenaeus vannamei fed (Duan et al., 2017). Based on the findings of Duan et al., 2017 study, 332 we aimed to analyse the effects of $C$. butyricum on growth, microbial composition in gut and 333 immune response of marron for the first time. Consistent with previous study by Duan et al., 334 (2017), we found significant $(\mathrm{P}<0.05)$ improvement of growth and protein content in tail muscle 335 of marron after 42 days of feeding trial. Besides this, C. butyricum supplementation in the diet also 
336 led to significantly increase the lysozyme and total haemocyte counts (THC) of haemolymph,

337 indicating the possibility of using C. butyricum as a probiotic supplements in marron aquaculture.

338 Intestine of crayfish is regarded as the centre for digestion and absorption of nutrients whereas

339 microbial communities present in the distal intestine play vital role in digestion and immunity

340 (Duan et al., 2017). Besides the available core microbiota, enrichment with some bacterial

341 communities facilitate to enhance the growth and immune performance of crayfish (Hoseinifar,

342 Sun, Wang, \& Zhou, 2018; E. Li et al., 2018). C. butyricum is a spore-forming butyric acid

343 producing bacteria, common in animal gut that has many beneficial characteristics to be used as

344 probiotic in poultry and aquaculture industry (Pan et al., 2008; Van Immerseel et al., 2010;

345 Takahashi et al., 2018). Butyric acid has been widely used for animal nutrition owing to its positive

346 effects on growth, intestinal digestion, absorption, metabolism and disease resistance (Robles et

347 al., 2013; Levy et al., 2015; Bourassa et al., 2016). The dietary supplementation of C. butyricum

348 in present study significantly (LDA $>2.0, \mathrm{P}<0.05)$ increased the abundance for Clostridium genus

349 in the marron gut leading to enhanced growth and immune performance. In addition to

350 Clostridium, the probiotic supplement also increased the richness of genus Cyanobium and

351 Illumatobacter. Both of these bacteria identified from the gut and water demonstrated to have

352 positive influence on remediation of water quality through the detoxification of pollutants and

353 minimization of hypoxia (Homonnay et al., 2012; Matsumoto et al., 2013; Wilhelm et al., 2014;

354 Naoum, 2016; Yamaguchi et al., 2016). The interactions among bacterial communities at phylum

355 to species level are very complex, a single probiotic bacteria can influence the growth of whole

356 microbial communities in the intestine of fish (Stubbendieck et al., 2016). A probiotic bacteria can

357 influence a wide range of biological processes in fish and crayfish including digestive enzymes,

358 immune systems (phagocyte activity, clearance efficacy), $\mathrm{pH}$ of gastrointestinal tract, nutrient 
359 availability etc. (Nayak, 2010; Sullak et al., 2012). And hence, in a study, inclusion of single

360 probiotic bacteria Bacillus subtilis in tilapia (Oreochromis niloticus) culture significantly $(\mathrm{P}<0.05)$

361 modulated the diversity of six genus (Giatsis et al., 2016), a very similar findings to present study.

362 At genus level, C. butyricum supplement significantly $(\mathrm{P}<0.05)$ reduced the Vibrio and Aeromonas

363 abundance in marron gut. Vibrio species has been associated with a number of diseases in crayfish

364 and also considered as emerging pathogen for marron (Ambas et al., 2013; Bean et al., 1998;

365 Momtaz, Foysal, Rahman, \& Fotedar, 2019). Aeromonas hydrophilla is widely reported as the

366 pathogen for many crayfish species including Pacifastacus leniusculus, Macrobrachium

367 rosenbergii (Jiravanichpaisal et al., 2009; Abdolnabi et al., 2015). Therefore, reduction of

368 abundance for these two bacteria from the fish gut represents positive impact of probiotic diet on

369 marron gut.

370 Although the use of probiotic bacteria for the growth and development of aquatic animals are

371 widespread, however, the mode of action of these bacteria in crayfish gut is yet not clear. To

372 investigate the effects of dietary C. butyricum supplementation on marron metabolic pathway, we

373 applied simple, commonly used and straight-forward online tool, Piphillin (Iwai et al., 2016). The

374 analysis predicted significantly higher activities for protein and energy metabolism, detoxification

375 and secondary metabolites synthesis in the probiotic fed group. Furthermore, the positive effects

376 of C. byturicum on crayfish, Litopenaeus vannamei growth, as reflected in terms of significant

377 increase in enzymatic pathways activities for the metabolism of carbohydrate and protein were

378 recorded (Duan et al., 2017). Consistent to this, our results predicted up-regulation of carbohydrate

379 metabolism and absorption, amino acids (glycine, serine, threonine and lysine) metabolism and

380 fatty acid metabolism. In addition, we also projected increased activities for biosynthesis of

381 secondary metabolites including prodigiosin, degradation of toxic compounds including organic 
382 (polycyclic aromatic hydrocarbon, PAHs) and synthetic (caprolactam) waste. High PAHs

383 concentration is harmful for aquatic life as they can persist for long time without being degraded

384 by the natural system while microbial mediated biological degradation has been reported in the

385 aquatic systems (Noverita Dian, Aryanti \& Nugraha, 2013). The present study was designed to

386 nurture marron without any filtration system, rather $30 \%$ water exchanged regularly. The untreated

387 organic waste accumulated from the faecal and excess feed therefore mostly settled in the button

388 of the tanks. The up-regulation of degradation pathway suggests bacterial decomposition of toxic

389 organic waste might also be associated with higher growth in the probiotic fed marron.

390 The profiling of immune responsive genes post bacterial challenge test were performed to

391 understand the role of probiotic feeding with the infection. Interleukins (IL) are the major class of

392 cytokines associated with the immunity of crayfish (Jiang et al., 2015). Dietary supplementation

393 of probiotic bacteria modulated the expression level of cytokine genes in fish (Panigrahi,

394 Viswanath \& Satoh, 2011; Zokaeifar et al., 2012; Selim \& Reda, 2015). Present study also revealed

395 significant upregulation of IL-17F and IL-10 expression in pathogen challenged marron. When

396 pro-inflammatory cytokine (i.e., IL-17F) are up-regulated in challenged fish, the anti-

397 inflammatory cytokine are also over-expressed to prevent the damage from inflammation (Miao

398 et al., 2018). Up-regulation of cytokine genes after feeding probiotic bacteria have been widely

399 authenticated as positive influence to enhance immune performance of fish (Panigrahi et al., 2007;

400 Yang et al., 2014; Miao et al., 2018). Two other significantly overexpressed genes,

401 prophenoloxidase (proPO) and cytosolic manganese superoxide dismutase (cytMnSOD) reported

402 to inhibit the growth of some crayfish pathogen i.e. shrimp white-spot virus (WSSV), Vibrio spp.,

403 and Aeromonas hydrophilla (Liu et al., 2013). Boosting immune performance by inhibition of

404 Vibrio and Aeromonas after dietary administration of $C$. butyricum is in accordance with the 
405 finding of Liu et al., (2013). Cathepsin L (PcCTSL) showed discrepancy in the expression level

406 with previous study (Dai et al., 2017) which possibly due to differences in the composition of feed

407 and shorter length of the previous study (two weeks).

\section{CONCLUSION}

409 In summary, cellular and molecular based study revealed that supplementation of $C$. butyricum as 410 a probiotic in feed improved growth performance, gut microbiota and immune response of marron.

411 Therefore, C. butyricum could be utilised as potential probiotic supplement in the diet of marron.

412 Further studies are required to reveal out the molecular mechanism of metabolic signalling 413 pathways for improving the immune performance induced by C. butyricum in marron.

\section{ACKNOWLEDGEMENT}

415 Authors are thankful to Australian Government for the financial support through Research 416 Training Program (RTP) scholarship.

\section{REFERENCES}

418

419

420

421

422

423

424

425

Abdel-Latif MA., El-Hack MEA., Swelum AA., Saadeldin IM., Elbestawy AR., Shewita RS., Ba-Awadh HA., Alowaimer AN., El-Hamid HSA. 2018. Single and combined effects of Clostridium butyricum and Saccharomyces cerevisiae on growth indices, intestinal health, and immunity of broilers. Animals 8. DOI: 10.3390/ani8100184.

Abdolnabi S., Ina-Salwany MY., Daud HM., Mariana NS., Abdelhadi YM. 2015. Pathogenicity of Aeromonas hydrophila in giant freshwater prawn; Macrobrachium rosenbergii, cultured in East Malaysia. Iranian Journal of Fisheries Sciences 14:232-245.

Albanese D., Fontana P., De Filippo C., Cavalieri D., Donati C. 2015. MICCA: A complete 
426

427

428

429

430

431

432

433

434

435

436

437

438

439

440

441

442

443

444

445

446

and accurate software for taxonomic profiling of metagenomic data. Scientific Reports 5:17. DOI: $10.1038 /$ srep09743.

Allali I., Arnold JW., Roach J., Cadenas MB., Butz N., Hassan HM., Koci M., Ballou A., Mendoza M., Ali R., Azcarate-peril MA. 2017. A comparison of sequencing platforms and bioinformatics pipelines for compositional analysis of the gut microbiome. $B M C$ Microbiology 17:1-16. DOI: 10.1186/s12866-017-1101-8.

Alonso AD. 2010. Marron farming in Western Australia: scope and constraints. British Food Journal 112:69-82. DOI: 10.1108/00070701011011218.

Ambas I., Fotedar R., Buller N. 2017. Synbiotic effect of Bacillus mycoides and organic selenium on immunity and growth of marron, Cherax cainii (Austin, 2002). Aquaculture Research 48:2729-2740. DOI: 10.1111/are.13105.

Ambas I., Suriawan A., Fotedar R. 2013. Immunological responses of customised probioticsfed marron, Cherax tenuimanus, (Smith 1912) when challenged with Vibrio mimicus. Fish and Shellfish Immunology 35:262-270. DOI: 10.1016/j.fsi.2016.07.028.

Andrews S. 2010. FastQC: a quality control tool for high throughput sequence data. 2010. DOI: citeulike-article-id:11583827.

Association of Official Agricultural Chemists (AOAC) AOAC official methods. 18th Edition Association of Official Analytical Chemists, Incorporated; Arlington: 2006 2006. $A O A C$.

Bean NH., Maloney EK., Potter ME., Korazemo P., Ray B., Taylor JP., Seigler S., Snowden J. 1998. Crayfish : A newly recognized vehicle for vibrio infections. Epidemiology 121:269273. 
447 Benito-Martin A., Peinado H. 2015. FunRich proteomics software analysis, let the fun begin! 448 Proteomics 15:2555-2556. DOI: 10.1002/pmic.201500260.

449 Bourassa MW., Alim I., Bultman SJ., Ratan RR. 2016. Butyrate, neuroepigenetics and the gut 450 microbiome: Can a high fiber diet improve brain health? Neuroscience Letters 625:56-63. DOI: 10.1016/j.neulet.2016.02.009.

452

453

454

455

456

457

458

459

460

461

462

463

464

465

466

467

468

Chen L., Li S., Zheng J., Li W., Jiang X., Zhao X., Li J., Che L., Lin Y., Xu S., Feng B., Fang Z., Wu D. 2018. Effects of dietary Clostridium butyricum supplementation on growth performance, intestinal development, and immune response of weaned piglets challenged with lipopolysaccharide. Journal of Animal Science and Biotechnology 9:1-14. DOI: 10.1186/s40104-018-0275-8.

Dabdoub SM., Fellows ML., Paropkari AD., Mason MR., Huja SS., Tsigarida AA., Kumar PS. 2016. PhyloToAST: Bioinformatics tools for species-level analysis and visualization of complex microbial datasets. Scientific Reports 6:1-9. DOI: 10.1038/srep29123.

Dai LS., Chu SH., Yu XM., Li YY. 2017. A role of cathepsin L gene in innate immune response of crayfish (Procambarus clarkii). Fish and Shellfish Immunology 71:246-254. DOI: 10.1016/j.fsi.2017.10.021.

Dawood MAO., Koshio S., Ishikawa M., Yokoyama S., El Basuini MF., Hossain MS., Nhu TH., Dossou S., Moss AS. 2016. Effects of dietary supplementation of Lactobacillus rhamnosus or/and Lactococcus lactis on the growth, gut microbiota and immune responses of red sea bream, Pagrus major. Fish and Shellfish Immunology 49:275-285. DOI: 10.1016/j.fsi.2015.12.047.

Department of Fisheries. 2017. Building a future for hairy marron. 
:http://www.fish.wa.gov.au/About-Us/News/Pages/Buil.

470

471

472

473

474

475

476

477

478

479

480

481

482

483

484

485

486

487

488

489

490

Didinen BI., Bahadir Koca S., Metin S., Diler O., Erol KG., Dulluc A., Koca HU., Yigit NO., Ozkok R., Kucukkara R. 2016. Effect of lactic acid bacteria and the potential probiotic Hafnia alvei on growth and survival rates of narrow clawed crayfish (Astacus leptodactylus Esch., 1823) stage II juveniles. Iranian Journal of Fisheries Sciences 15:1307-1317.

Duan Y., Zhang Y., Dong H., Wang Y., Zheng X., Zhang J. 2017. Effect of dietary Clostridium butyricum on growth, intestine health status and resistance to ammonia stress in Pacific white shrimp Litopenaeus vannamei. Fish and Shellfish Immunology 65:25-33. DOI: 10.1016/j.fsi.2017.03.048.

Eaves LE., Ketterer PJ. 1994. Mortalities in red claw crayfish Cherax quadricarinatus associated with systemic Vibrio mimicus infection. Diseases of Aquatic Organisms 19:233-237. DOI: 10.3354/dao019233.

Foysal J., Fotedar R., Tay C-Y., Gupta SK. 2019. Dietary supplementation of black soldier fly (Hermetica illucens) meal modulates gut microbiota, innate immune response and health status of marron (Cherax cainii, Austin 2002) fed poultry-by-product and fishmeal based diets. PeerJ 7:e6891. DOI: 10.7717/peerj.6891.

Gao Q., Xiao Y., Sun P., Peng S., Yin F., Ma X., Shi Z. 2013. In vitro protective efficacy of Clostridium butyricum against fish pathogen infections. Indian Journal of Microbiology 53:453-459. DOI: 10.1007/s12088-013-0394-z.

Giatsis C., Sipkema D., Ramiro-garcia J., Bacanu GM., Abernathy J., Verreth J., Smidt H., Verdegem M. 2016. Probiotic legacy effects on gut microbial assembly in tilapia larvae. Scientific Reports 6:1-11. DOI: 10.1038/srep33965. 
491

492

493

494

495

496

497

498

499

500

501

502

503

504

505

506

507

508

509

510

511

512

Hoang TC., Cole AJ., Fotedar RK., O’Leary MJ., Lomas MW., Roy S. 2016. Seasonal changes in water quality and Sargassum biomass in southwest Australia. Marine Ecology Progress Series 551:63-79. DOI: 10.3354/meps11735.

Homonnay ZG., Kéki Z., Márialigeti K., Tóth EM. 2012. Bacterial communities in the gut of the freshwater copepod Eudiaptomus gracilis. Journal of Basic Microbiology 52:86-90. DOI: 10.1002/jobm.201100052.

Hoseinifar SH., Sun YZ., Wang A., Zhou Z. 2018. Probiotics as means of diseases control in aquaculture, a review of current knowledge and future perspectives. Frontiers in Microbiology 9:1-18. DOI: 10.3389/fmicb.2018.02429.

Van Immerseel F., Ducatelle R., De Vos M., Boon N., Van De Wiele T., Verbeke K., Rutgeerts P., Sas B., Louis P., Flint HJ. 2010. Butyric acid-producing anaerobic bacteria as a novel probiotic treatment approach for inflammatory bowel disease. Journal of Medical Microbiology 59:141-143. DOI: 10.1099/jmm.0.017541-0.

Irianto A., Austin B. 2002. Probiotics in aquaculture. Journal of Fish Diseases 25:633-642. DOI: 10.1046/j.1365-2761.2002.00422.x.

Iwai S., Weinmaier T., Schmidt BL., Albertson DG., Poloso NJ., Dabbagh K., DeSantis TZ. 2016. Piphillin: Improved prediction of metagenomic content by direct inference from human microbiomes. PLoS ONE 11:1-18. DOI: 10.1371/journal.pone.0166104.

Iwashita MKP., Nakandakare IB., Terhune JS., Wood T., Ranzani-Paiva MJT. 2015. Dietary supplementation with Bacillus subtilis, Saccharomyces cerevisiae and Aspergillus oryzae enhance immunity and disease resistance against Aeromonas hydrophila and Streptococcus iniae infection in juvenile tilapia Oreochromis niloticus. Fish and Shellfish Immunology 
43:60-66. DOI: 10.1016/j.fsi.2014.12.008.

514

515

516

517

518

519

520

521

522

523

524

525

526

527

528

529

530

531

532

533

Jiang H., Qian Z., Lu W., Ding H., Yu H., Wang H., Li J. 2015. Identification and characterization of reference genes for normalizing expression data from red swamp crawfish Procambarus clarkii. International Journal of Molecular Sciences 16:21591-21605. DOI: $10.3390 /$ ijms 160921591.

Jim F., Garamumhango P., Musara C. 2017. Comparative analysis of nutritional value of Oreochromis niloticus (Linnaeus), Nile tilapia, meat from three different ecosystems. Journal of Food Quality 2017:ID 674347. DOI: 10.1155/2017/6714347.

Jiravanichpaisal P., Roos S., Edsman L., Liu H., Söderhäll K. 2009. A highly virulent pathogen, Aeromonas hydrophila, from the freshwater crayfish Pacifastacus leniusculus. Journal of Invertebrate Pathology 101:56-66. DOI: 10.1016/j.jip.2009.02.002.

Joshi N., Fass J. 2011. sickle - A windowed adaptive trimming tool for FASTQ files using quality. (Version 1.33):[Software].

Kesarcodi-Watson A., Kaspar H., Lategan MJ., Gibson L. 2008. Probiotics in aquaculture: The need, principles and mechanisms of action and screening processes. Aquaculture 274:1-14. DOI: 10.1016/j.aquaculture.2007.11.019.

Kongnum K., Hongpattarakere T. 2012. Effect of Lactobacillus plantarum isolated from digestive tract of wild shrimp on growth and survival of white shrimp (Litopenaeus vannamei) challenged with Vibrio harveyi. Fish and Shellfish Immunology 32:170-177. DOI: 10.1016/j.fsi.2011.11.008.

Kuczynski J., Stombaugh J., Walters WA., González A., Caporaso JG., Knight R. 2012. 
Using QIIME to analyze 16s rRNA gene sequences from microbial communities. Current Protocols in Microbiology s36:1-20. DOI: 10.1002/9780471729259.mc01e05s27.

Lawrence C. 2007. Improved performance of marron using genetic and pond management strategies. Fisheries Research Contract Report 17:1-178.

Levy AW., Kessler JW., Fuller L., Williams S., Mathis GF., Lumpkins B., Valdez F. 2015. Effect of feeding an encapsulated source of butyric acid (ButiPEARL) on the performance of male Cobb broilers reared to $42 \mathrm{~d}$ of age. Poultry science 94:1864-1870.

Li J., Tan B., Mai K. 2009. Dietary probiotic Bacillus OJ and isomaltooligosaccharides influence

Li E., Xu C., Wang X., Wang S., Zhao Q., Zhang M., Qin JG., Chen L. 2018. Gut microbiota the intestine microbial populations, immune responses and resistance to white spot syndrome virus in shrimp (Litopenaeus vannamei). Aquaculture 291:35-40. DOI: 10.1016/j.aquaculture.2009.03.005. and its modulation for healthy farming of Pacific white shrimp Litopenaeus vannamei. Reviews in Fisheries Science and Aquaculture 26:381-399. DOI:

Liu YT., Chang CI., Hseu JR., Liu KF., Tsai JM. 2013. Immune responses of prophenoloxidase 10.1080/23308249.2018.1440530.

Liu H., Li J., Guo X., Liang Y., Wang W. 2018. Yeast culture dietary supplementation modulates and cytosolic manganese superoxide dismutase in the freshwater crayfish Cherax quadricarinatus against a virus and bacterium. Molecular Immunology 56:72-80. DOI: 10.1016/j.molimm.2013.03.023.

gut microbiota, growth and biochemical parameters of grass carp. Microbial Biotechnology 11:551-565. DOI: 10.1111/1751-7915.13261. 
556 Mahanty A., Purohit GK., Mohanty S., Nayak NR., Mohanty BP. 2017. Suitable reference

557 gene for quantitative real-time PCR analysis of gene expression in gonadal tissues of minnow

558 Puntius sophore under high-temperature stress. BMC Genomics 18:1-9. DOI:

$559 \quad 10.1186 / \mathrm{s} 12864-017-3974-1$.

560

561

562

563

564

565

566

567

568

569

570

571

572

573

574

575

576

577

Mai H Van., Fotedar R. 2018. Haemolymph constituents and osmolality as functions of moult stage, body weight, and feeding status in marron, Cherax cainii (Austin and Ryan, 2002) and yabbies, Cherax destructor (Clark, 1936). Saudi Journal of Biological Sciences 25:689-696. DOI: 10.1016/j.sjbs.2016.03.007.

Mai H., Fotedar R., Fewtrell J. 2010. Evaluation of Sargassum sp. as a nutrient-sink in an integrated seaweed-prawn (ISP) culture system. Aquaculture 310:91-98. DOI: 10.1016/j.aquaculture.2010.09.010.

Matsumoto A., Kasai H., Matsuo Y., Shizuri Y., Ichikawa N., Fujita N., Omura S., Takahashi Y. 2013. Ilumatobacter nonamiense sp. nov. and Ilumatobacter coccineum sp. nov., isolated from seashore sand. International Journal of Systematic and Evolutionary Microbiology 63:3404-3408. DOI: 10.1099/ijs.0.047316-0.

Miao S., Zhao C., Zhu J., Hu J., Dong X., Sun L. 2018. Dietary soybean meal affects intestinal homoeostasis by altering the microbiota, morphology and inflammatory cytokine gene expression in northern snakehead. Scientific Reports 8:1-10. DOI: 10.1038/s41598-017$18430-7$

Mirarab S., Nguyen N., Guo S., Wang L-S., Kim J., Warnow T. 2015. PASTA: Ultra-large multiple sequence alignment for nucleotide and amino-acid sequences. Journal of Computational Biology 22:377-386. DOI: 10.1089/cmb.2014.0156. 
578 Momtaz F., Foysal J., Rahman M., Fotedar R. 2019. Design of epitope based vaccine against

579 shrimp white spot syndrome virus (WSSV) by targeting the envelope proteins: An 580 immunoinformatic approach. Turkish Journal of Fisheries and Aquatic Sciences 19:149-159.

581 DOI: $10.4194 / 1303-2712-v 19 \_2 \_07$.

582 583

Naoum JO. 2016. Study of bacterial populations from oligotrophic soil ecosystems using high throughput sequencing technologies. PhD Thesis:1-197.

Nayak SK. 2010. Role of gastrointestinal microbiota in fish. Aquaculture Research 41:15531573. DOI: $10.1111 / \mathrm{j} .1365-2109.2010 .02546 . x$.

Noverita Dian T., Aryanti ST., Nugraha MA. 2013. Concentration of polycyclic aromatic hydrocarbon (PAHs) in the sediments and milkfish (Chanos chanos, Forsk) at Marunda and Blanakan ponds, Indonesia. International Journal of Marine Science 3:105-110. DOI: 10.5376/ijms.2013.03.0013.

Nugroho RA., Fotedar R. 2013. Growth, Survival and Physiological Condition of Cultured Marron,. Journal of Agricultural Science and Technology 3:125-135.

Oksanen AJ., Blanchet FG., Kindt R., Legen- P., Minchin PR., Hara RBO., Simpson GL., Soly- P., Stevens MHH., Wagner H. 2018. Package “vegan.” :[Software].

Pan X., Wu T., Zhang L., Song Z., Tang H., Zhao Z. 2008. In vitro evaluation on adherence and antimicrobial properties of a candidate probiotic Clostridium butyricum CB2 for farmed fish. Journal of Applied Microbiology 105:1623-1629. DOI: $10.1111 / \mathrm{j} .1365-$ 2672.2008.03885.x.

Panigrahi A., Kiron V., Satoh S., Hirono I., Kobayashi T., Sugita H., Puangkaew J., Aoki T. 
599

600

601

602

603

604

605

606

607

608

609

610

611

612

613

614

615

616

617

618

619

620

2007. Immune modulation and expression of cytokine genes in rainbow trout Oncorhynchus mykiss upon probiotic feeding. Developmental and Comparative Immunology 31:372-382. DOI: 10.1016/j.dci.2006.07.004.

Panigrahi A., Viswanath K., Satoh S. 2011. Real-time quantification of the immune gene expression in rainbow trout fed different forms of probiotic bacteria Lactobacillus rhamnosus. Aquaculture Research 42:906-917. DOI: 10.1111/j.1365-2109.2010.02633.x.

Parikh HI., Koparde VN., Bradley SP., Buck GA., Sheth NU. 2016. MeFiT: Merging and filtering tool for illumina paired-end reads for $16 \mathrm{~S}$ rRNA amplicon sequencing. $B M C$ Bioinformatics 17:1-6. DOI: 10.1186/s12859-016-1358-1.

Pirarat N., Kobayashi T., Katagiri T., Maita M., Endo M. 2006. Protective effects and mechanisms of a probiotic bacterium Lactobacillus rhamnosus against experimental Edwardsiella tarda infection in tilapia (Oreochromis niloticus). Veterinary Immunology and Immunopathology 113:339-347. DOI: 10.1016/j.vetimm.2006.06.003.

Quast C., Pruesse E., Yilmaz P., Gerken J., Schweer T., Yarza P., Peplies J., Glöckner FO. 2013. The SILVA ribosomal RNA gene database project: Improved data processing and webbased tools. Nucleic Acids Research 41:590-596. DOI: 10.1093/nar/gks1219.

Ramírez NCB., Rodrigues MS., Guimarães AM., Guertler C., Rosa JR., Seiffert WQ., Andreatta ER., Vieira F do N. 2017. Effect of dietary supplementation with butyrate and probiotic on the survival of Pacific white shrimp after challenge with Vibrio alginolyticus. Revista Brasileira de Zootecnia 46:471-477. DOI: 10.1590/S1806-92902017000600001.

Robles R., Lozano AB., Sevilla A., Márquez L., Nuez-Ortín W., Moyano FJ. 2013. Effect of partially protected butyrate used as feed additive on growth and intestinal metabolism in sea 
621

622

623

624

625

626

627

628

629

630

631

632

633

634

635

636

637

638

639

640

641

bream (Sparus aurata). Fish Physiology and Biochemistry 39:1567-1580. DOI: 10.1007/s10695-013-9809-3.

Sang HM., Fotedar R. 2004. Growth, survival, haemolymph osmolality and organosomatic indices of the western king prawn (Penaeus latisulcatus Kishinouye, 1896) reared at different salinities. Aquaculture 234:601-614. DOI: 10.1016/j.aquaculture.2004.01.008.

Segata N., Izard J., Waldron L., Gevers D., Miropolsky L., Garrett WS., Huttenhower C. 2011. Metagenomic biomarker discovery and explanation. Genome Biology 12:R60. DOI: 10.1186/gb-2011-12-6-r60.

Selim KM., Reda RM. 2015. Improvement of immunity and disease resistance in the Nile tilapia, Oreochromis niloticus, by dietary supplementation with Bacillus amyloliquefaciens. Fish and Shellfish Immunology 44:496-503. DOI: 10.1016/j.fsi.2015.03.004.

Sherry YM El., Mahmoud MM., Hassan ES., Mustafa SI., Elkamel AA. 2016. Subclinical vibriosis in red swamp crayfish, Procambarus clarkii. International Journal of Fisheries and Aquatic Studies 4:119-123.

Skelton J., Geyer KM., Lennon JT., Creed RP., Brown BL. 2017. Multi-scale ecological filters shape the crayfish microbiome. Symbiosis 72:159-170. DOI: 10.1007/s13199-016-0469-9.

Song Z., Wu T., Cai L., Zhang L., Zheng X. 2006. Effects of dietary supplementation with Clostridium butyricum on the growth performance and humoral immune response in Miichthys miiuy. Journal of Zhejiang University SCIENCE B 7:596-602. DOI: 10.1016/j.gaceta.2011.03.011.

Stubbendieck RM., Vargas-bautista C., Straight PD., Romero DF., Beauregard P. 2016. 
642 643 644 645 646 647

Bacterial communities: Interactions to scale. Frontiers in Microbiology 7:1-19. DOI: 10.3389/fmicb.2016.01234.

Sullam KE., Essinger SD., Lozupone CA., O'Connor MP., Rosen GL., Knight R., Kilham SS., Russell JA. 2012. Environmental and ecological factors that shape the gut bacterial communities of fish: A meta-analysis. Molecular Ecology 21:3363-3378. DOI: 10.1111/j.1365-294X.2012.05552.x.

Takahashi M., McCartney E., Knox A., Francesch M., Oka K., Wada K., Ideno M., Uno K., Kozłowski K., Jankowski J., Gracia MI., Morales J., Kritas SK., Esteve-Garcia E., Kamiya S. 2018. Effects of the butyric acid-producing strain Clostridium butyricum MIYAIRI 588 on broiler and piglet zootechnical performance and prevention of necrotic enteritis. Animal Science Journal 89:895-905. DOI: 10.1111/asj.13006.

Wang AR., Ran C., Ringø E., Zhou ZG. 2018. Progress in fish gastrointestinal microbiota research. Reviews in Aquaculture 10:626-640. DOI: 10.1111/raq.12191.

Wilhelm SW., Lecleir GR., Bullerjahn GS., Mckay RM., Saxton MA., Twiss MR., Bourbonniere RA. 2014. Seasonal changes in microbial community structure and activity imply winter production is linked to summer hypoxia in a large lake. FEMS Microbiology Ecology 87:475-485. DOI: 10.1111/1574-6941.12238.

Yamaguchi H., Shimura Y., Suzuki S., Yamagishi T., Tatarazako N., Kawachi M. 2016. Complete genome sequence of Cyanobium sp. NIES-981, a marine strain potentially useful for ecotoxicological bioassays. Genome Announcements 4:e00736-16. DOI: 10.1128/genomeA.00736-16.

Yang HL., Xia HQ., Ye YD., Zou WC., Sun YZ. 2014. Probiotic Bacillus pumilus SE5 shapes 
664 the intestinal microbiota and mucosal immunity in grouper Epinephelus coioides. Diseases 665 of Aquatic Organisms 111:119-127. DOI: 10.3354/dao02772.

666 Zhang L., Cao GT., Zeng XF., Zhou L., Ferket PR., Xiao YP., Chen AG., Yang CM. 2014. 667 Effects of Clostridium butyricum on growth performance, immune function, and cecal 668 microflora in broiler chickens challenged with Escherichia coli K88. Poultry Science 93:46669 53. DOI: $10.3382 / \mathrm{ps} .2013-03412$.

670 Zheng X., Duan Y., Dong H., Zhang J. 2017. Effects of dietary Lactobacillus plantarum in 671 different treatments on growth performance and immune gene expression of white shrimp 672 Litopenaeus vannamei under normal condition and stress of acute low salinity. Fish and 673 Shellfish Immunology 62:195-201. DOI: 10.1016/j.fsi.2017.01.015.

674 Zokaeifar H., Balcázar JL., Saad CR., Kamarudin MS., Sijam K., Arshad A., Nejat N. 2012. 675 Effects of Bacillus subtilis on the growth performance, digestive enzymes, immune gene 676 expression and disease resistance of white shrimp, Litopenaeus vannamei. Fish and Shellfish 677 Immunology 33:683-689. DOI: 10.1016/j.fsi.2012.05.027. 


\section{Table $\mathbf{1}$ (on next page)}

Feed ingredients and proximate composition (\% dry weight) of the diet used in this study

*All ingredients were procured and feeds were formulated by Glen Forest Specialty Feeds, Western Australia.

Abbreviation: $\mathrm{CP}=$ Crude protein; $\mathrm{GE}=$ Gross energy; $\mathrm{MJ}=$ Mega joule

†Final proximate composition of the experimental diet 


\begin{tabular}{lc}
\hline Ingredients* & Basal diet \\
\hline Fishmeal & 41 \\
Soya bean meal & 10 \\
Wheat & 37 \\
Corn starch & 4.80 \\
Cod liver oil & 4.20 \\
CaCO 3 & 0.02 \\
Vitamin premix & 0.23 \\
Vitamin C & 0.05 \\
Cholesterol & 0.50 \\
Lecithin-Soy & 1 \\
Betacaine & 1.20 \\
Total & 100 \\
\hline${ }^{\dagger C P} \%$ & 29.93 \\
${ }^{\dagger}$ Lipid \% & 7.12 \\
${ }^{\dagger}$ GE MJ kg ${ }^{-1}$ & 18.21 \\
${ }^{\dagger}$ C. butyricum CFU/mL & $1.01 \times 10^{7}$ \\
\hline
\end{tabular}

1 


\section{Table 2 (on next page)}

Primers used for gene expression analysis in present study

Abbreviation: $\mathrm{IL}=$ Interleukin, PcCTSL $=$ Cathepsin L, proPO $=$ Prophenoloxidase, $c y t M n S O D=$ Cytosolic manganese superoxide dismutase 


\begin{tabular}{|c|c|c|c|}
\hline $\begin{array}{l}\text { Primer } \\
\text { name }\end{array}$ & Forward sequence $\left(5^{\prime}-3^{\prime}\right)$ & Reverse sequence $\left(5^{\prime}-3^{\prime}\right)$ & Reference \\
\hline proPO & GCCAAGGATCTTTGTGATGTCTT & CGGCCGGCCAGTTCTAT & Liu et al., 2013 \\
\hline cytMnSOD & AGGTCGAGCAAGCAGGTGTAG & GTGGGAATAAACTGCAGCAATCT & Liu et al., 2013 \\
\hline PcCTSL & CGGATCACTGGAGGGTCAAACACTT & GCAATTTTCATCCTCGGCATCAT & Dai et al., 2017 \\
\hline IL-8 & CTATTGTGGTGTTCCTGA & TCTTCACCCAGGGAGCTTC & Miao et al., 2018 \\
\hline IL-10 & CAGTGCAGAAGAGTCGACTGCAAG & CGCTTGAGATCCTGAAATATA & Miao et al., 2018 \\
\hline IL-17F & GTCTCTGTCACCGTGGAC & TGGGCCTCACACAGGTACA & Miao et al., 2018 \\
\hline$\beta$-actin & TTGAGCAGGAGATGGGAACCG & AGAGCCTCAGGGCAACGGAAA & Miao et al., 2018 \\
\hline
\end{tabular}

1 


\section{Table 3(on next page)}

Mean \pm SE of some health parameters of marron after feeding trials

Abbreviation: WG $=$ Weight gain; $S G R=$ Specific growth rate; $H M=$ Hepatopancreas moisture; $\mathrm{THC}=$ Total haemocyte count; $\mathrm{HO}=$ Haemolymph osmolality. ${ }^{*}$ Significantly different at $\alpha$-level of 0.05 . $\mathbf{f F r o m}$ tail muscle. " From hepatopancreas 


\begin{tabular}{lll}
\hline Parameters & Control & Probiotic \\
\hline WG & $21.66 \pm 1.78$ & $26.24 \pm 0.81^{*}$ \\
SGR & $0.45 \pm 0.034$ & $0.53 \pm 0.031^{*}$ \\
Protein $\dagger$ & $84.4 \pm 0.57$ & $88.7 \pm 0.83^{*}$ \\
Energy $\dagger$ & $20038.8 \pm 56.06$ & $20241.1 \pm 88.25$ \\
Fat & $8.8 \pm 0.09$ & $8.4 \pm 0.06$ \\
Lysozyme & $0.42 \pm 0.005$ & $0.48 \pm 0.009^{*}$ \\
THC & $8.2 \pm 0.09$ & $9.5 \pm 0.21^{*}$ \\
HO & $0.41 \pm 0.004$ & $0.44 \pm 0.011$ \\
\hline
\end{tabular}

1 


\section{Table 4 (on next page)}

Diversity index (Mean $\pm \mathrm{SE}$ ) of bacterial genus in marron gut after feeding trials *Significantly different at $\alpha$-level of 0.05 . **Significantly different at $\alpha$-level of 0.005 . ***Significantly different at $\alpha$-level of 0.001 


\begin{tabular}{cccccc}
\hline Condition & OTUs (SE) & Shannon (SE) & $\begin{array}{c}\text { Simpson } \\
\text { (SE) }\end{array}$ & $\begin{array}{c}\text { Fisher } \\
\text { alpha (SE) }\end{array}$ & Chao1 (SE) \\
\hline Control & $15.8(1.9)$ & $1.51(0.1)$ & $0.69(0.1)$ & $7.59(0.2)$ & $86.74(5.8)$ \\
Probiotic & $30.3(11.5)$ & $3.19(0.1)^{* * *}$ & $0.82(0.1)^{* *}$ & $16.7(2.1)^{*}$ & $128.48(8.6)^{*}$ \\
\hline
\end{tabular}

1 
Figure 1

(A) Multiple regression analysis showing the relationship between the number of moults and health indices of marron after trial; (B) PCoA plot displaying the separation of marron regarding moult counts in two different feeding conditions 

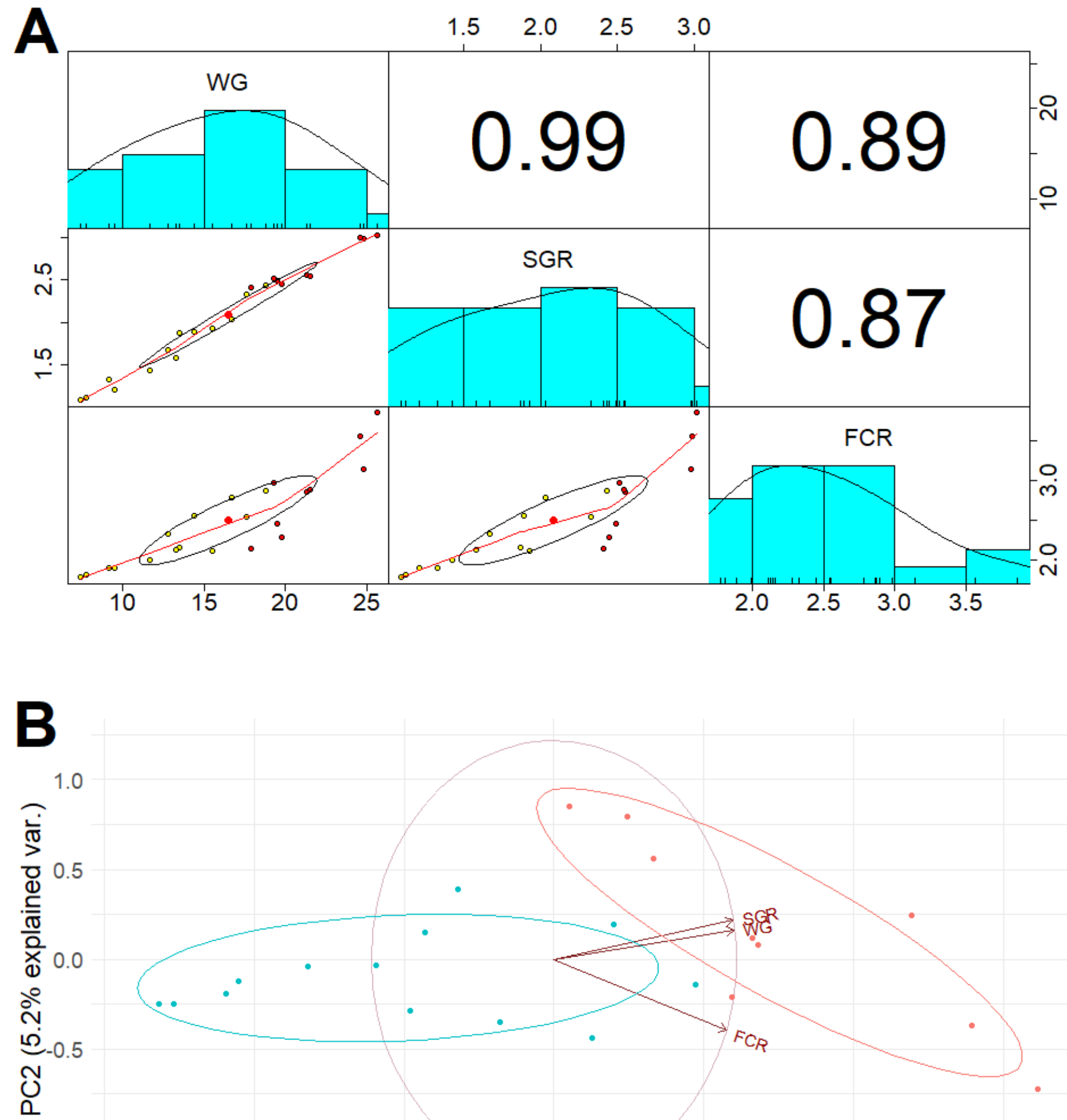

$-1.0$

$-2$

0

PC1 (94.5\% explained var.)

$\rightarrow$ Moulted $\rightarrow$ Non-moulted 
Figure 2

PCoA plot representing the impacts of two different feeds on gut microbial communities of marron after 42 days of feeding trial.

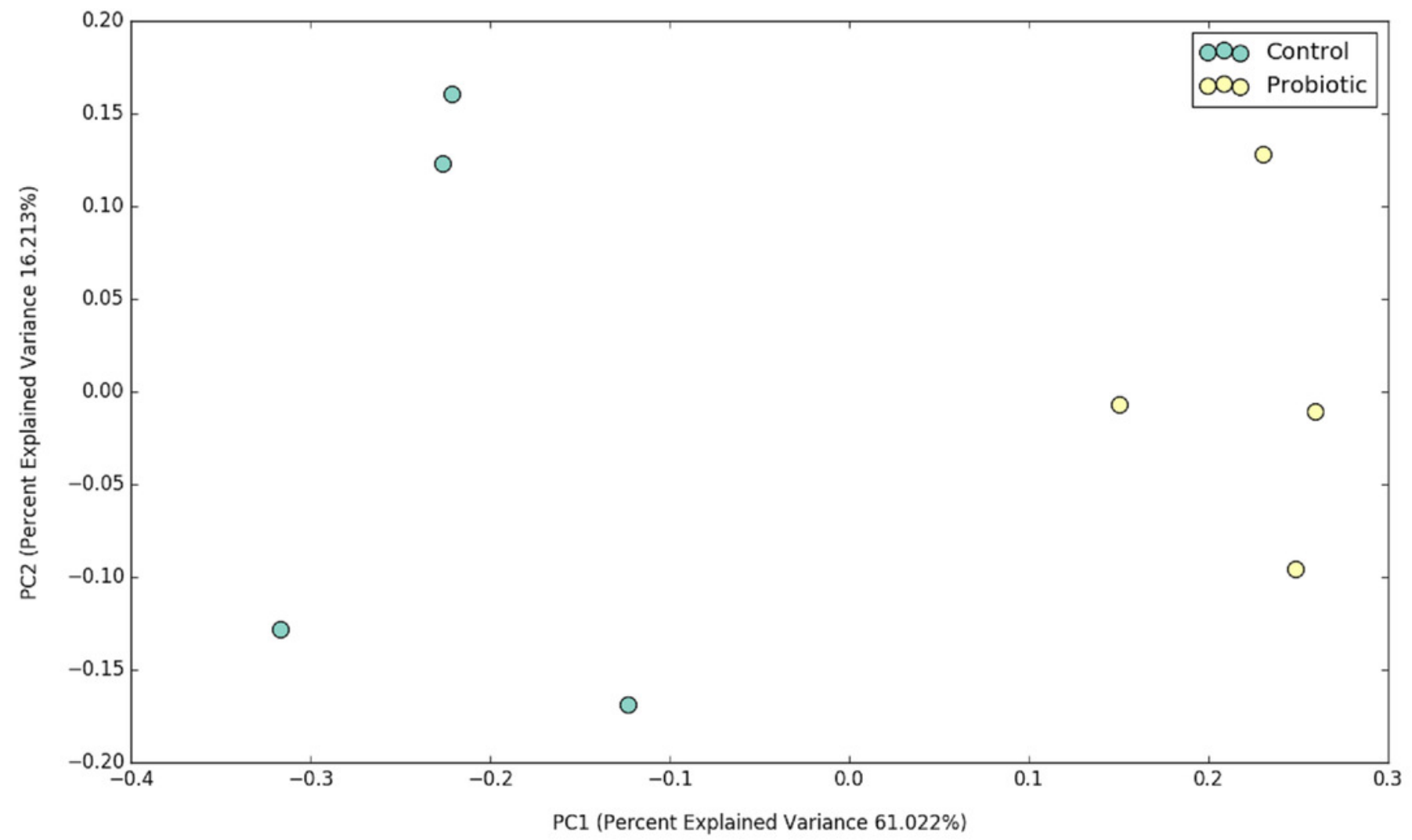


Figure 3

(A) Venn diagram showing shared and unshared genus in two different groups; (B) Box plots exhibiting the species richness in two different feeding conditions after trial. 


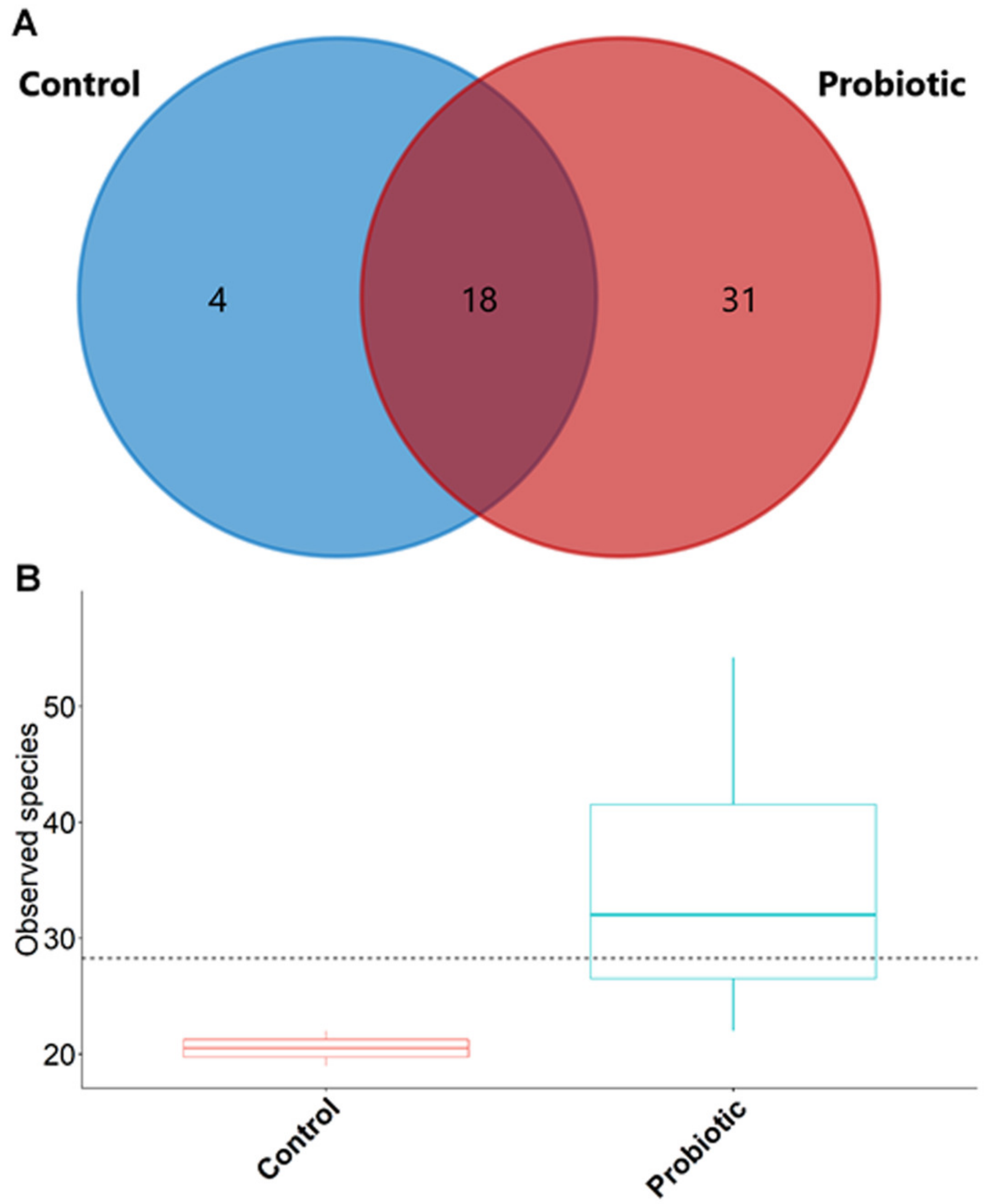


Figure 4

Microbial communities in two different fed groups after trial; (A) Relative abundance of bacterial OTUs at phylum level; (B) Relative abundance of bacterial OTUs at genus level. 

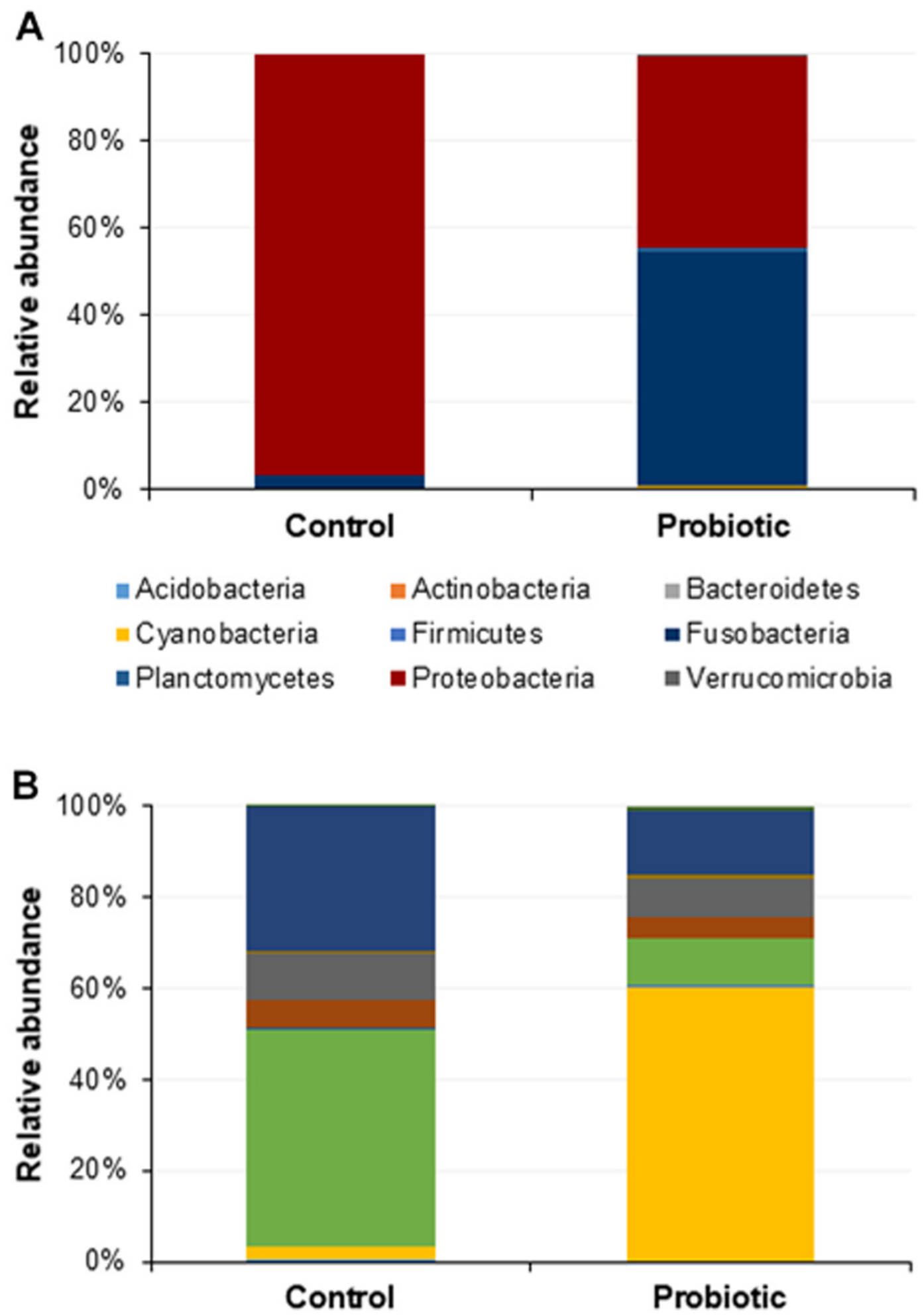
= Flavo bacterium
=Cyanobium
$=$ Clostridium
- Hypnocyclicus
=Rhodobacter
= Aeromonas
- Shewanella - Citrobacter
a Raoultella
- Pseudomonas
-Vibrio
- Arenimonas 
Figure 5

(A) Indicator bacterial genus in two different conditions (control and probiotic) with LDA value 2.0 or more; (B) Predicted metabolic pathways in two different fed groups revealed from $16 \mathrm{~S}$ rRNA sequence data using Piphillin and LEfSe package 


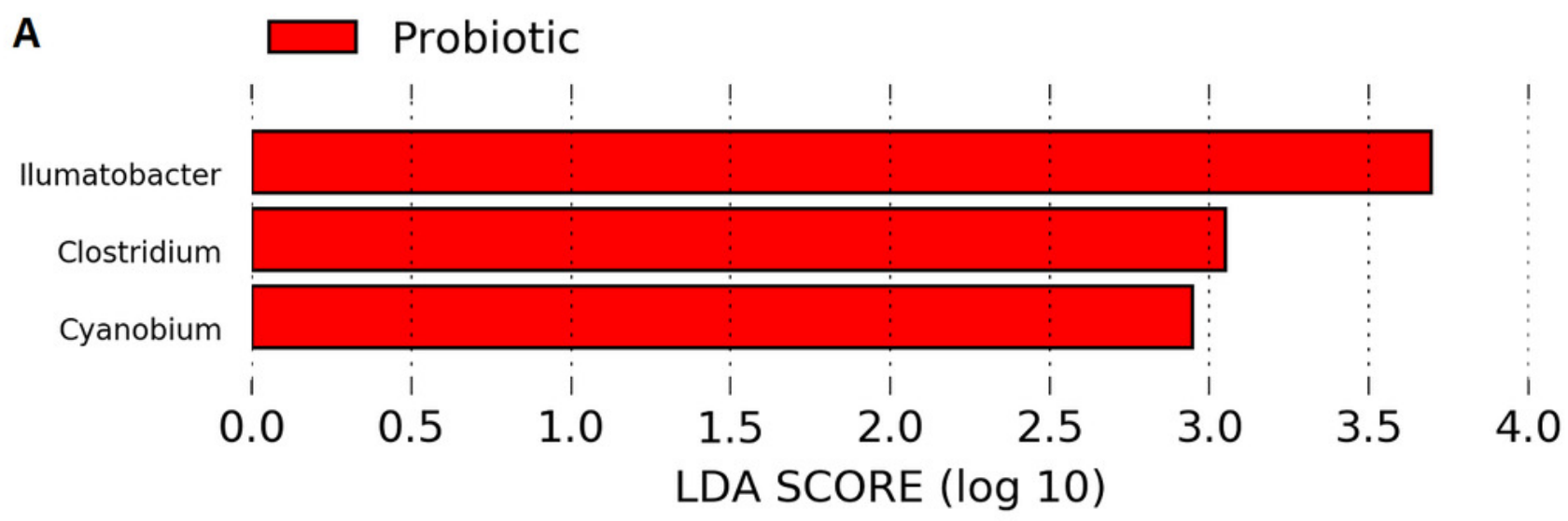

B $\square$ Probiotic $\square$ Control

Carbohydrate digestion and absorption Glycine serine and threonine metabolism

Lysine degradation

Fatty acid degradation Prodigiosin biosynthesis Polycyclic aromatic hydrocarbon degradation Amyotrophic lateral sclerọsis_ALS Caprolactam degradation Biosynthesis of secondary metabolites
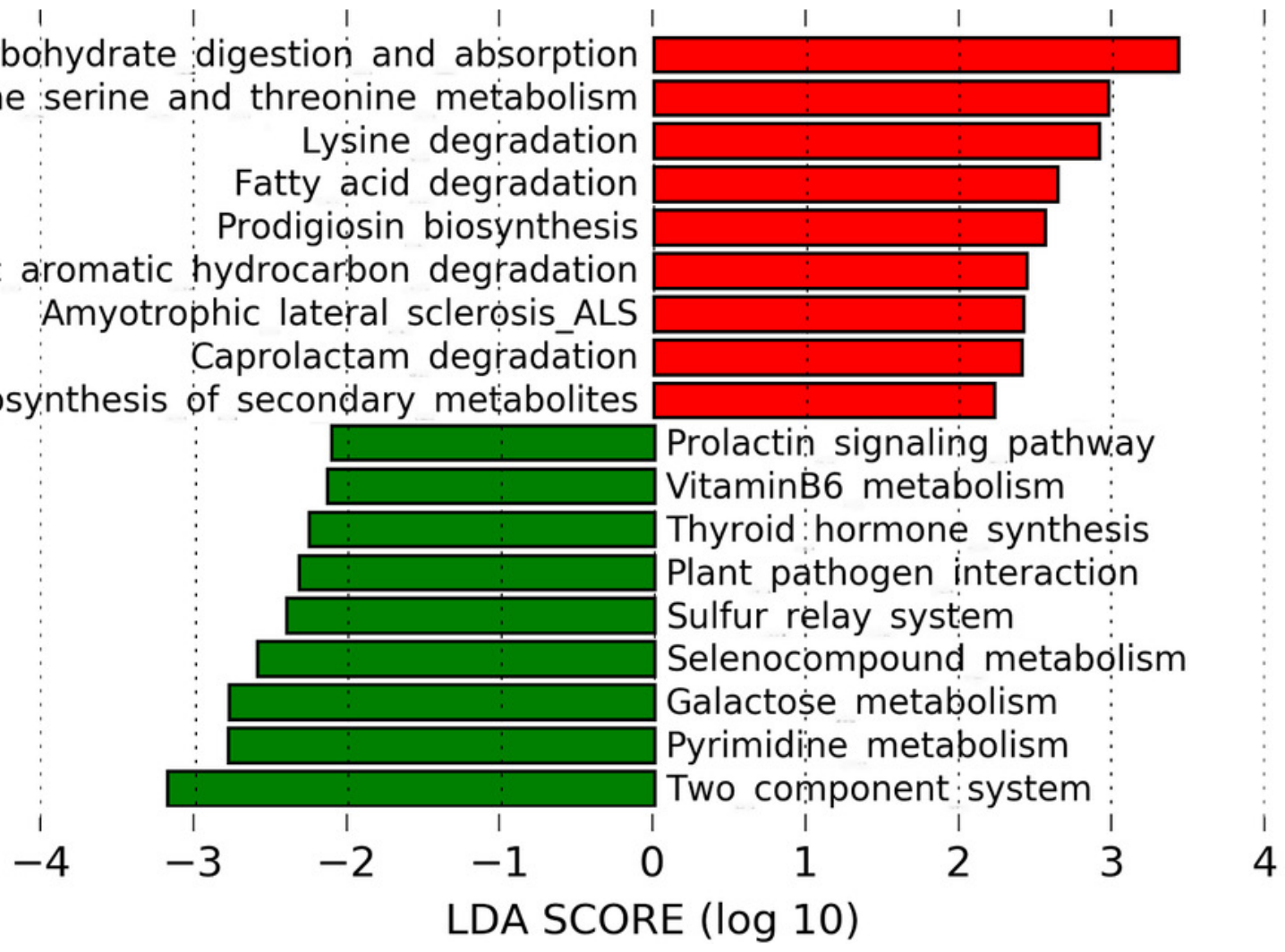
Figure 6

Barplot showing the relative expression level of immune genes in marron intestine tissue after feeding trial

*Significantly different at $\alpha$-level of 0.05 . **Significantly different at $\alpha$-level of 0.005

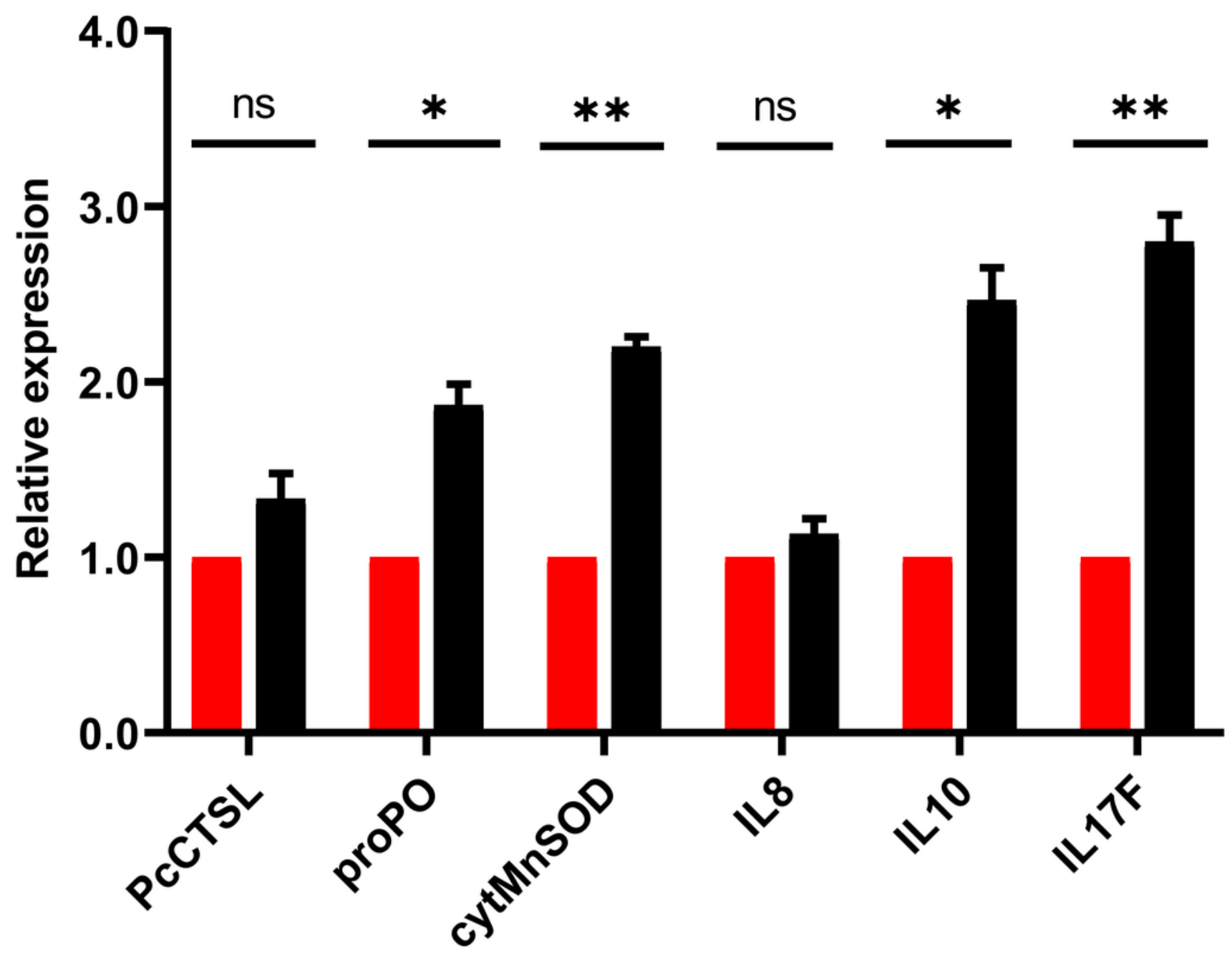

